\title{
Evaluation of Drinking Water Needs in Wae Decer, Manggarai Regency, Nusa Tenggara Timur Province
}

\author{
Rr Diah Nugraheni Setyowati", Rahmad Junaidi, Efa Suriani, Teguh Taruna Utama \\ Faculty of Science and Technology, UIN Sunan Ampel Surabaya Jl. Ahmad Yani 117 Surabaya \\ Email: diahnugraheni@uinsby.ac.id
}

\begin{abstract}
Drinking water is a basic need for humans. The provision of drinking water throughout Indonesia is an obligation that has been stated in UUD 45. Based on the Bappenas study with the Ministry of Public Works, universal access to drinking water is targeted to reach $84,8 \%$ nationally. Then, this universal access must increase to $92,2 \%$ in 2018 . In the end, access to drinking water for the community in 2019 is $100 \%$. Based on this description, every region in Indonesia must have universal access to proper drinking water. Manggarai Regency is one of the districts that will alleviate the problem of universal access to drinking water. Existing water sources in Manggarai Regency are in various locations of hills and mountains. This water source is a source of water that can be used as a source of drinking water. Based on the study of SPAM Master Plan, residents of Manggarai Regency who have had access to adequate drinking water are $57.61 \%$. The percentage value is still below the threshold of decent MDGs in 2015 which is $68 \%$. Considering that the target of fulfilling universal access to drinking water in 2019 is $100 \%$, it is necessary to have a major breakthrough in drinking water supply in Manggarai Regency. One way that needs to be done is to evaluate the drinking water needs. Based on the results of a field survey, Manggarai District has the potential of drinking water sources of $150 \mathrm{Lps}$, water has been utilized by $30 \mathrm{Lps}$ and the services to be developed are $40 \mathrm{Lps}$. The method used in this research is quantitative descriptive method. The results of the analysis obtained from the study on the evaluation of drinking water needs are long-term drinking water needs in 8 (eight villages), the capacity of clean water from Wae Decer water spring cannot supply drinking water by 2029. In 2028, the remaining clean water capacity from MA. Wae Decer only has 0.16 liters per second. If Wae Decer SPAM wants to be extended to 2037 according to long-term planning, then in 2018 the required supply capacity is 48,15 liters per second. The difference of 8,15 liters per second can be taken from Wae Decer which still has the remaining idle capacity of 77 liters per second in 2037. This capacity can be used for the development of drinking water reaching other villages that intersect with the DED Wae Decer system and or added from source of springs adjacent to Wae Decer clean water network.
\end{abstract}

Keywords: Drinking water, Evaluate, Source, Water needs

\section{INTRODUCTION}

Drinking water is a basic need for humans. Provision of drinking water throughout Indonesia is an obligation that has been stated in the 1945 Constitution. Inevitably, the growth of occupation in every Indonesian territory will affect the supply of drinking water in the future. Based on a Bappenas study with the Ministry of Public Works, universal access to drinking water is targeted to reach $84,8 \%$ nationally. Then, this universal access must increase to $92,2 \%$ in 2018. In the end, access to drinking water for the community in 2019 is $100 \%$. The government's target is in line with the $100-0-100$ program in the Government of Indonesia's Medium Term Development Plan in 2019. Based on this description, every region in Indonesia, both in urban and rural areas, has at least universal access to adequate drinking water to reach all levels of society. The principle of drinking water supply in urban and rural areas in general has been stated in the form of analysis of District SPAM Master Plans. The SPAM Master Plan, referred to as RISPAM, is a technical description of the supply of drinking water including the sources of raw water available in the Regency. Then, the other chapters will discuss the number of residents who will be served until the target of the ninth year that has been agreed by all relevant SKPD in the Regency.
Manggarai Regency is one of the districts that will alleviate the problem of universal access to drinking water. In 2019, Manggarai Regency is expected to have fulfilled the universal access to drinking water that has been planned in the 2016 Manggarai Regency RISPAM guidebook. Based on the RISPAM study, residents in Manggarai Regency who have had access to decent drinking water are $57,61 \%$, well served by PDAM piping system and rural water supply. This percentage value is still below the 2015 MDGs decent threshold of $68 \%$. Considering that the target of fulfilling universal access to drinking water in 2019 is $100 \%$, it is necessary to have a major breakthrough in drinking water supply in Manggarai Regency. Therefore, the District Government of Manggarai needs to do development quickly and precisely, especially in regional areas that do not have access to adequate drinking water. With the potential of drinking water sources of $150 \mathrm{Lps}$, water has been utilized by $30 \mathrm{LPs}$ and the service to be developed is $40 \mathrm{Lps}$. A rough assumption for 1 LP can serve 80 families, so with a debit of 40 Lps can serve up to 3200 families. Manggarai Regency has an administrative area of $13,795.07 \mathrm{~km}^{2}$.

Manggarai Regency is part of the province of East Nusa Tenggara, astronomically located between $8^{\circ}-8^{\circ}$ $30^{\prime}$ South Latitude and $119^{\circ} 30-121^{\circ} 30^{\prime}$ East Longitude. The administrative area of Manggarai 
Regency originally consisted of 9 Districts and 171 Villages. Sub-district subdistricts in Manggarai namely, Langke Rembong District, Wae Ri, Cibal, Reok, North Rahong, Ruteng, Lelak, Satar Mane and Satar Mese. After the expansion, the area of Manggarai Regency is $1,669.42 \mathrm{Km}^{2}$, or $166,942 \mathrm{Ha}$. Administratively it is divided into 12 sub-districts, 145 villages and 26 sub- districts, with the Manggarai District Government Center in Ruteng City Langke Rembong District. Three sub-districts are division subdistricts from Ruteng and Satar Mese sub-districts. The following is a picture of Manggarai Regency administration map.

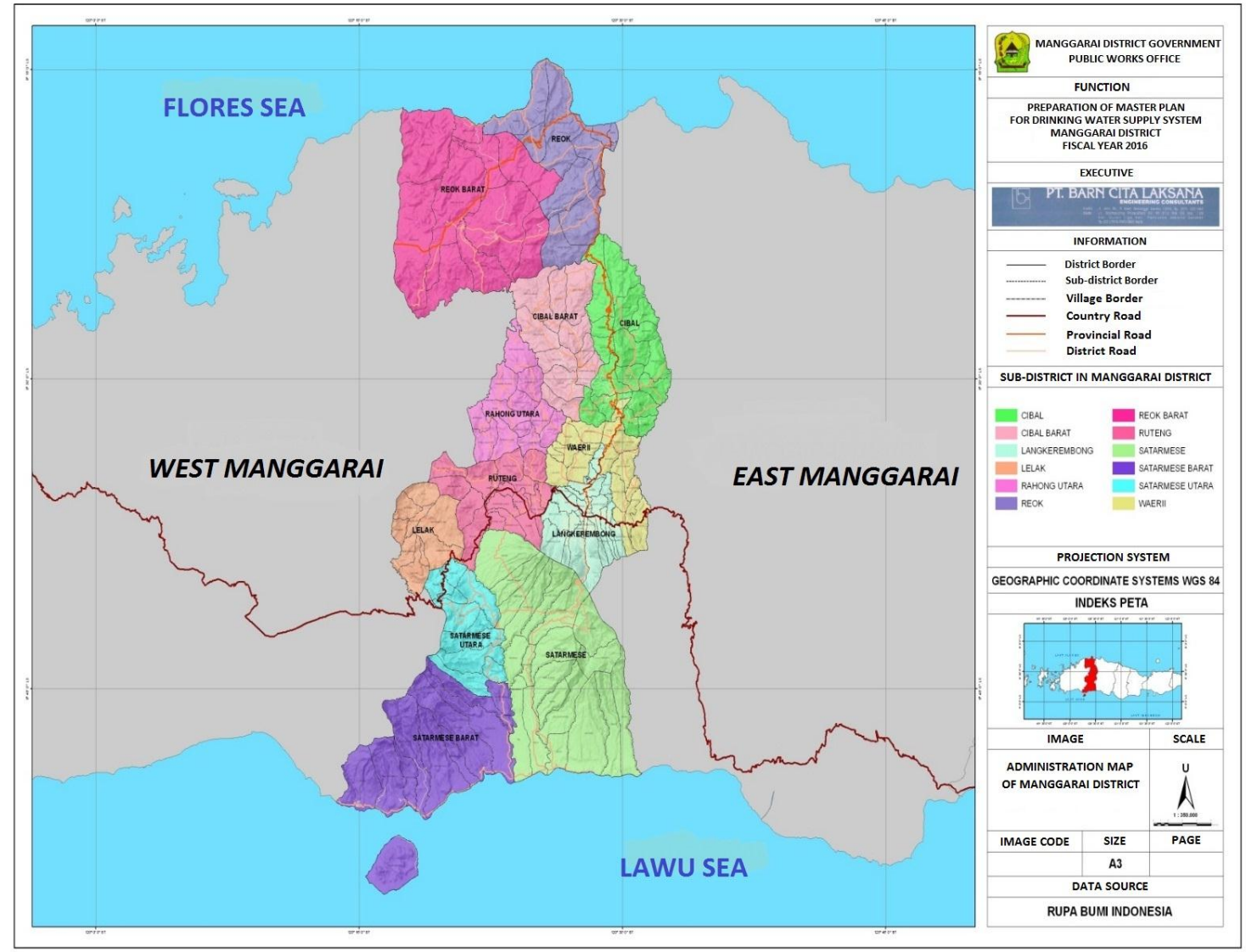

Figure 1. Administrative map of Manggarai Regency (Public Works Ministry, 2016).

Like several regions in the eastern part of Indonesia, Manggarai Regency includes tropical climates consisting of 2 seasons rainy and dry seasons. The average air temperature ranges about $15.00^{\circ} \mathrm{C}$ to $24.70^{\circ}$ $\mathrm{C}$, with an average of $19.70^{\circ} \mathrm{C}$, and an average humidity level of $84 \%$. According to L.R. Oldeman, which divides the area into Agroclimatic zones, based on the criteria of wet months (more than 200 $\mathrm{mm} /$ month) and dry months (less than $100 \mathrm{~mm} /$ month) indicates that Manggarai District tends to be included in wet areas, with sufficient rainfall high but not evenly distributed in each sub-district area. The average rainfall is $2,440.9 \mathrm{~mm}$, with an average wet month every year is 7 (seven) months. Manggarai Regency is seen from its topography as a highland area dominated by the shape of a bumpy (mountainous) land surface. From an area of $166,942 \mathrm{Ha}$. As much as $23,98 \%$ is a land at an altitude between 100-200 meters from the sea level. Higher plains, between 300 - 500 meters reach almost $26 \%$. While the land area is above 500 meters, it reaches almost $6 \%$ of the total area of Manggarai Regency. Likewise the slope of the land, dominated by slopes ranging from $15-25 \%$ and the slope between 25 $40 \%$ which spread in each sub-district area.

\section{MATERIALS AND METHODS}

\section{Study Area}

The hydrological condition in Manggarai Regency consists of water sources derived from groundwater, surface water and rainfall. As an area that has mountainous surfaces, groundwater is generally 
obtained from springs that come from mountainous areas that still have a fairly tight type of flora from tree plants. Some of the major rivers where the water flows throughout the year include Wae Pesi, Wae Nuring, Wae Renca which flows and empties into the North Coast (Reok Subdistrict), and the Wae Naong River, Wae Reno and Wae Mese flow southwards and lead to the Coast South (Satar Mese District). The important source of groundwater in Manggarai Regency is the existence of Golo Lusang Mountain, Poco Ranaka and other mountains.

Existing water sources in Manggarai Regency are in various locations of hills and mountains. This water source is a source of water that can be used as a source of drinking water. In the RISPAM Kabupaten planning document, the physiography of the Manggarai area is in a mountainous location and has a Manggarai groundwater basin. Manggarai Regency is rich in potential springs. Therefore, the raw water source used by the Manggarai District PDAM comes from springs. In 2016, there were 21 sources of raw water for PDAMs, villages and villages. In total there are 41 villages served by this system.

The current total capacity reaches 178 liters/second. The source of the spring is taken from several springs and then flowed by gravity. Some water sources are channeled into the reservoir, some are channeled directly to customers by gravity. Clean water services in Manggarai Regency are carried out by the Manggarai Regency PDAM. Deed of establishment (over status function) of the Drinking Water Management Agency dated April 5, 1991. PERDA of Manggarai Regency Number 2 of 1991 concerning Establishment of Regional Water Supply Company at the same level as Manggarai Regency.

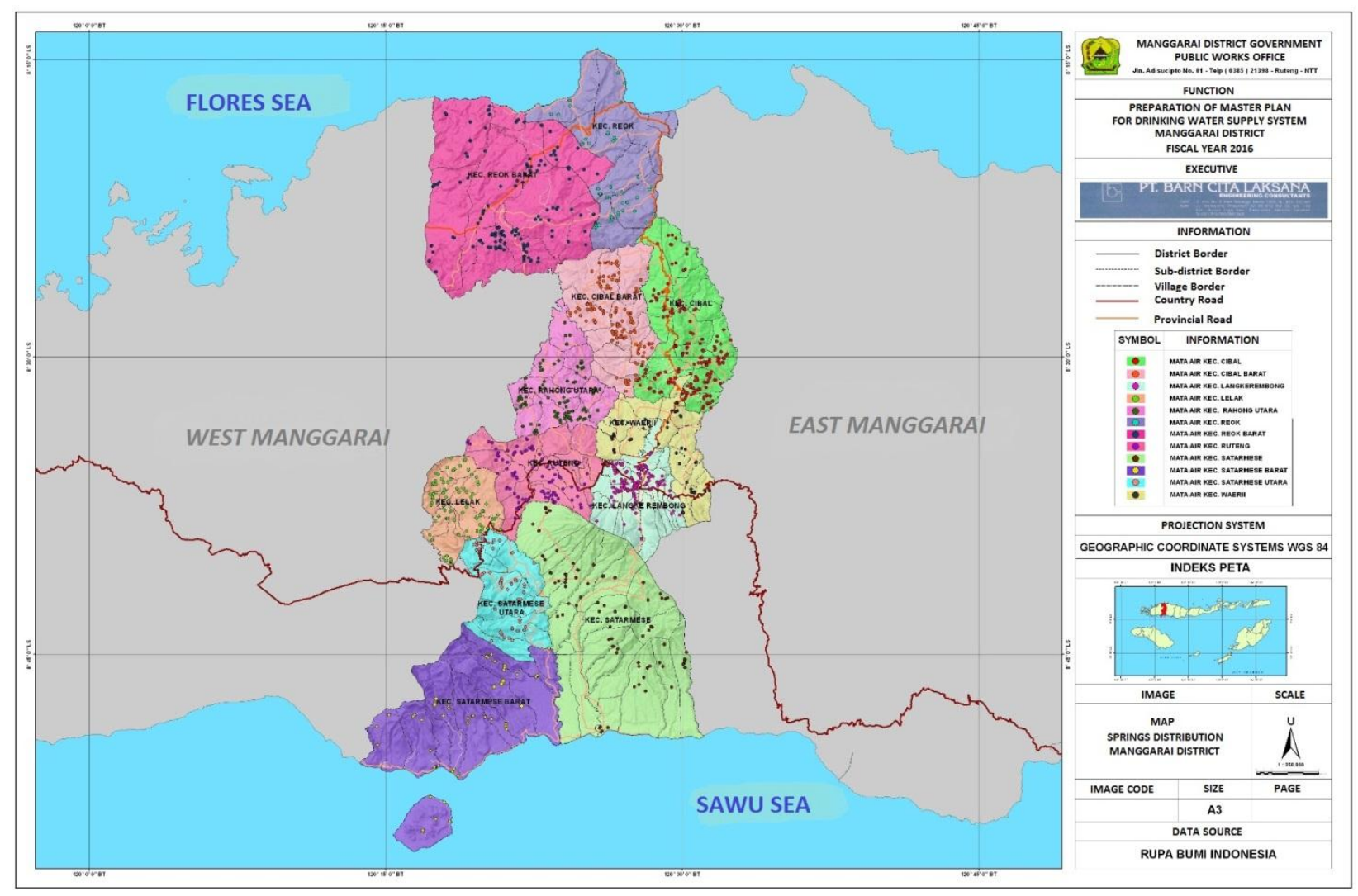

Figure 2. Spring distribution map in Manggarai Regency (Public Works Ministry, 2016).

\section{Procedures}

This research was conducted with quantitative descriptive method. Descriptive research is research conducted to determine the value of an independent variable, either one variable or more (independent) without making comparisons, or connecting with other variables. While quantitative understanding is research conducted by obtaining data in the form of numbers or qualitative data. In this study also uses statistical methods that support the calculation of water needs in 
the area. Prediction of the number of residents and city facilities in the future is very important in calculating the amount of drinking water needs in the future. This prediction is based on the rate of urban development and trends, directives for land use and availability of land to accommodate population growth. By paying attention to the rate of development of the population and city facilities of the past, the statistical method is the closest method to estimate the population and facilities of the city in the future. In accordance with the population prediction method that has been submitted for population projections in Manggarai Regency will use arithmetic methods, geomatics methods and exponential methods.

Arithmetic methods are used when periodic data shows the same amount of addition each year. This happens in cities with small areas, the level of economic growth in the city is low and the development of the city is not too fast. Geometric Method for population projection needs, this method is used if the population data shows a rapid increase over time. The exponential method with 2 stages of projection, which is the projection for the population of the Regency, then distributes it to each subdistrict to village using the percentage of the population of the district to the population of the district as well as the percentage of the village population towards the subdistrict population. The average population growth in Manggarai Regency in the last 5 years was 2,07\%, against the district average. Where the average population growth in Manggarai Regency in the last 5 years amounted to $2,07 \%$, against the district average, obtained some facts from the average population growth of each district, namely

Growth is far above average (High Growth/UP), which includes sub-districts; Langke Rembong with a growth percentage of $4,59 \%$, Satar Mese Barat with a percentage of $3,82 \%$, Satar Mese $2,95 \%$, Kecamatan Lelak $2,75 \%$.

- Growth around the average down, which includes districts; West Reok and West Cibal with a growth percentage of 2,26\% and 2,10\%.

- While other sub-districts Growth below average (Under Average Growth/ DOWN).

\section{Data Analysis}

Predicting the number of residents and city facilities in the future is very important in calculating the amount of drinking water needs in the future. This prediction is based on the rate of urban development and trends, directives for land use and availability of land to accommodate population growth. Before estimating the need for clean water, the population has been projected with the following results.
Table 1. Projected population.

\begin{tabular}{cllll}
\hline \multirow{2}{*}{ No } & \multirow{2}{*}{ Sub-district } & \multicolumn{3}{c}{ Projected Population } \\
\cline { 3 - 5 } 1 & Wae RII & 44.529 & $\mathbf{2 0 3 5}$ & $\mathbf{2 0 3 6}$ \\
\hline 2 & Ruteng & 67.434 & 68.832 & 46.394 \\
3 & Satar Mese & 54.572 & 55.703 & 70.259 \\
4 & Cibal & 40.259 & 41.094 & 41.958 \\
5 & Reok & 30.838 & 31.477 & 32.129 \\
6 & Langke Rembong & 106.016 & 108.214 & 110.457 \\
7 & West Satar Mese & 30.312 & 30.940 & 31.582 \\
8 & North Rahong & 36.513 & 37.270 & 38.042 \\
9 & Lelak & 19.986 & 20.401 & 20.824 \\
10 & West Reok & 22.280 & 22.742 & 23.213 \\
11 & West Cibal & 23.500 & 23.987 & 24.484 \\
12 & North Satar Mese & 23.383 & 23.868 & 24.362 \\
\multicolumn{2}{c}{ Total } & $\mathbf{4 9 9 . 6 2 1}$ & $\mathbf{5 0 9 . 9 7 8}$ & $\mathbf{5 2 0 . 5 5 0}$ \\
\hline
\end{tabular}

Note: Results of Data Analysis.

Estimates of the need for clean water in this discussion are calculated based on water needs per capita, population growth and development, and classification of types of needs. It should also be taken into account the development of the economic level and the ability of providers to serve the development of clean water needs in the future. The issuance of PP $16 / 2005$ which requires water providers to be able to distribute potable water in 2026 must also be considered. For the needs of clean water to be used in the calculation, it is set at $100 \mathrm{~L} /$ person/day up to 150 L/person/day for the Urban/IKK system at the end of the planning year. Whereas for rural areas 60 $1 t /$ person/day. In estimating the need for clean water also includes domestic water needs, non-domestic water needs, water loss and reservoir volume/capacity.

\section{RESULTS AND DISCUSSION}

\section{Result-1}

Based on the results of the projection of drinking water demand for SPAM Wae Decer, medium-term drinking water needs at 8 (eight), the capacity of clean water from Wae Decer will still give the remaining 0.97 liters per second in 2027. If the first stage of SPAM Wae Decer discharge is planned by 40 seconds, the drinking water supply at SPAM Wae Decer will reach the maximum discharge usage in 2027. In 2028, the SPAM debit needs to be increased from the available debit (idle capacity) of the MA Wae Decer. Capacity of Idle from Wae Decer spring in 2028, this capacity will be maximized to secure clean water supply up to 2037 . The following is a table and graph of the development of drinking water needs and the potential discharge of MA Wae Decer which is mutually mutable to longterm projections in 2027. 
Table 2. Recapitulation of drinking water needs for DED SPAM wae decer up to 2027.

\begin{tabular}{|c|c|c|c|c|c|c|c|c|c|c|c|c|}
\hline \multirow{2}{*}{ NO } & \multirow{2}{*}{ VILLAGE } & \multicolumn{11}{|c|}{ YEAR } \\
\hline & & 2017 & 2018 & 2019 & 2020 & 2021 & 2022 & 2023 & 2024 & 2025 & 2026 & 2027 \\
\hline 1 & Ranggi & 1.24 & 1.77 & 2.72 & 3.42 & 3.58 & 3.74 & 3.91 & 4.09 & 4.28 & 4.48 & 4.68 \\
\hline 2 & Bangka Kenda & 2.16 & 3.01 & 4.61 & 5.65 & 5.76 & 5.87 & 5.99 & 6.11 & 6.23 & 6.35 & 6.48 \\
\hline 3 & Golo Wua & 0.80 & 1.11 & 1.71 & 2.09 & 2.14 & 2.18 & 2.22 & 2.27 & 2.31 & 2.36 & 2.40 \\
\hline 4 & Golo Watu & 1.70 & 2.37 & 3.63 & 4.45 & 4.54 & 4.63 & 4.72 & 4.81 & 4.91 & 5.01 & 5.11 \\
\hline 5 & Wae Mulu & 1.83 & 2.54 & 3.90 & 4.78 & 4.88 & 4.97 & 5.07 & 5.17 & 5.27 & 5.38 & 5.48 \\
\hline 6 & Liang Bua & 2.25 & 3.08 & 4.73 & 5.70 & 5.71 & 5.73 & 5.74 & 5.76 & 5.77 & 5.79 & 5.80 \\
\hline \multirow[t]{6}{*}{8} & Bere & 1.78 & 2.48 & 3.81 & 4.67 & 4.77 & 4.87 & 4.97 & 5.08 & 5.18 & 5.29 & 5.40 \\
\hline & Service Level (\%) & 58 & 70 & 90 & 100 & 100 & 100 & 100 & 100 & 100 & 100 & 100 \\
\hline & Total Water & 12.98 & 18.07 & 27.71 & 33.94 & 34.61 & 35.30 & 36.01 & 36.74 & 37.48 & 38.25 & 39.03 \\
\hline & Wae Decer Supply & 40.00 & 40.00 & 40.00 & 40.00 & 40.00 & 40.00 & 40.00 & 40.00 & 40.00 & 40.00 & 40.00 \\
\hline & Remain Capacity & 27.02 & 21.93 & 12.29 & 6.06 & 5.39 & 4.70 & 3.99 & 3.26 & 2.52 & 1.75 & 0.97 \\
\hline & Idle Capacity & 77.00 & 77.00 & 77.00 & 77.00 & 77.00 & 77.00 & 77.00 & 77.00 & 77.00 & 77.00 & 77.00 \\
\hline
\end{tabular}

Note: Results of Data Analysis.

And this is a graph of the projection of drinking water demand for Wae Decer SPAM until 2027.

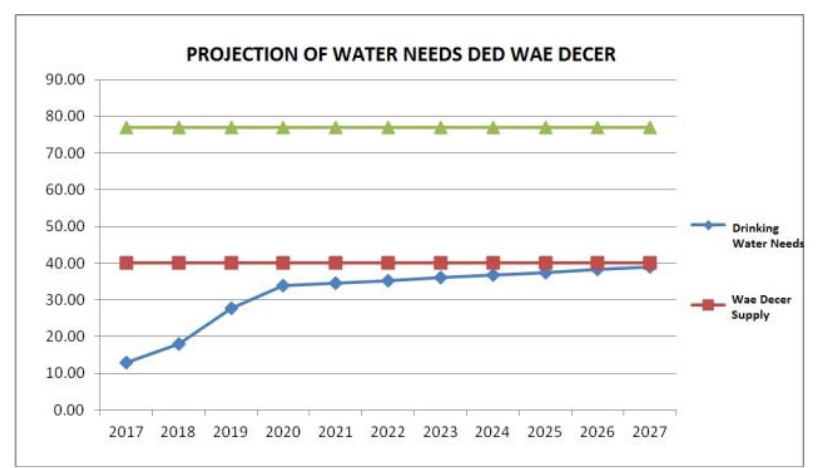

Figure 3. Projection of drinking water needs for we decer until 2027 (Results of Data Analysis).

\section{Result-2}

Based on the results of the calculation of the projected drinking water needs of SPAM Wae Decer, long-term drinking water needs in 8 (eight villages), the capacity of clean water from Mata Air Decer cannot supply drinking water by 2029 . By 2028, the remaining clean water capacity from MA. Wae Decer only has 0,16 liters per second. If Wae Decer SPAM wants to be extended to 2037 according to long-term planning, then in 2018 the required supply capacity is 48,15 liters per second. The difference of 8,15 liters per second can be taken from Wae Decer which still has the remaining idle capacity of 77 liters per second in 2037. This capacity can be used for the development of drinking water reaching other villages that intersect with the DED Wae Decer system and or added from source of springs adjacent to Wae Decer clean water network. The following is a table and graph of the development of drinking water needs and the potential discharge of MA Wae Decer which is mutually diversified until the long-term projection in 2037.

Table 3. Recapitulation of drinking water needs for DED SPAM wae decer up to 2037.

\begin{tabular}{|c|c|c|c|c|c|c|c|c|c|c|c|}
\hline \multirow{2}{*}{ NO } & \multirow{2}{*}{ VILLAGE } & \multicolumn{10}{|c|}{ YEAR } \\
\hline & & 2028 & 2029 & 2030 & 2031 & 2032 & 2033 & 2034 & 2035 & 2036 & 2037 \\
\hline 1 & Ranggi & 4.90 & 5.06 & 5.30 & 5.54 & 5.79 & 6.06 & 6.34 & 6.63 & 6.93 & 7.33 \\
\hline 2 & Bangka Kenda & 6.61 & 6.70 & 6.84 & 6.97 & 7.11 & 7.25 & 7.39 & 7.54 & 7.69 & 7.88 \\
\hline 4 & Golo Watu & 5.21 & 5.28 & 5.39 & 5.50 & 5.60 & 5.71 & 5.83 & 5.94 & 6.06 & 6.21 \\
\hline 5 & Wae Mulu & 5.52 & 5.60 & 5.72 & 5.84 & 5.96 & 6.09 & 6.22 & 6.35 & 6.48 & 6.65 \\
\hline 6 & Liang Bua & 5.59 & 5.68 & 5.79 & 5.90 & 6.02 & 6.14 & 6.26 & 6.38 & 6.51 & 6.67 \\
\hline \multirow[t]{6}{*}{8} & Bere & 3.76 & 3.82 & 3.90 & 3.98 & 4.06 & 4.15 & 4.23 & 4.32 & 4.41 & 4.53 \\
\hline & Service Level (\%) & 100 & 100 & 100 & 100 & 100 & 100 & 100 & 100 & 100 & 100 \\
\hline & Total Water & 39.84 & 40.46 & 41.30 & 42.17 & 43.06 & 43.98 & 44.92 & 45.88 & 46.88 & 48.15 \\
\hline & Wae Decer Supply & 40.00 & 40.00 & 40.00 & 40.00 & 40.00 & 40.00 & 40.00 & 40.00 & 40.00 & 40.00 \\
\hline & Remain Capacity & 0.16 & -0.46 & -1.30 & -2.17 & -3.06 & -3.98 & -4.92 & -5.88 & -6.88 & -8.15 \\
\hline & Idle Capacity & 77.00 & 77.00 & 77.00 & 77.00 & 77.00 & 77.00 & 77.00 & 77.00 & 77.00 & 77.00 \\
\hline
\end{tabular}

Note: Results of Data Analysis. 
And this is a graph of the projection of drinking water demand for Wae Decer SPAM until 2037

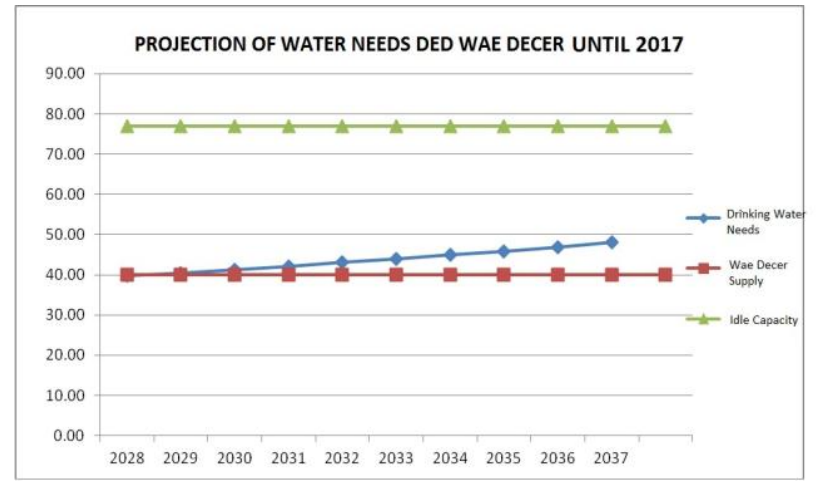

Figure 4. Projection of drinking water needs for wae decer until 2037 (Results of Data Analysis).

\section{Discussion}

Based on the evaluation of projection of drinking water needs for the long term, the drinking water needs of SPAM Wae Decer will increase to 48,15 liters per second in 2037. By 2037, the need for drinking water reaching 48,15 liters per second will provide the remaining capacity of drinking water 69,85 liters per second. With this remaining capacity, PDAM also needs to consider the distribution of water at the MA Wae Decer source with irrigation and agriculture needs. Surplus MA debit. Wae Decer can be a source of drinking water development and or is not used specifically for irrigation canal irrigation. However, note that this scenario must work out if the MA Wae Decer debit is maintained at a fixed capacity for at least 10 years. Therefore, the need for conservation efforts in the source of the MA upstream. Wae Decer so that there will be no natural damage and damage to the catchment area resulting in a decrease in the discharge of the spring.

\section{CONCLUSIONS}

Based on the results of a field survey, Manggarai District has the potential of drinking water sources of $150 \mathrm{Lps}$, water has been utilized by $30 \mathrm{Lps}$ and the services to be developed are $40 \mathrm{Lps}$. The results of the study on the evaluation of drinking water needs are long-term drinking water needs in 8 (eight villages), the capacity of clean water from Wae Decer water spring cannot supply drinking water by 2029. In 2028, the remaining clean water capacity from MA. Wae Decer only has 0.16 liters per second. If Wae Decer SPAM wants to be extended to 2037 according to long-term planning, then in 2018 the required supply capacity is 48,15 liters per second. The difference of 8,15 liters per second can be taken from Wae Decer which still has the remaining idle capacity of 77 liters per second in 2037. This capacity can be used for the development of drinking water reaching other villages that intersect with the DED Wae Decer system and or added from source of springs adjacent to Wae Decer clean water network.

\section{ACKNOWLEDGMENTS}

Thank you to BPS, Bappenas, Ministry of Public Works, Konindo Consultant, Government and people of Manggarai Regency, NTT who have helped this research and all parties we cannot mention one by one.

\section{REFERENCES}

Bujar H.Durmisi, et al. 2015. Evaluation of Physico-Chemical Quality of Drinking Water with Drinking Water Quality Index in Kumanova City, Macedonia. 1-1

Fikrat M. Hassan, et al. 2017. Evaluate the Efficiency of Drinking Water Treatment Plants in Baghdad City - Iraq. Journal of Applied \& Environmental Microbiology. 6-1

Gary A.Burlingame, et al. 2017. Humans as Sensors to Evaluate Drinking Water Taste and Odor: A Review. American Water Works Association Journal. 109-11

Kepmenkes RI No. 907/Menkes/SK/VII/2002

Leonardo Mena, et al. 2018. Assessment of drinking water suitability in low income rural areas: a case study in Sixaola, Costa Rica. Water and Health Journal. 16-3

Permenkes No.416/Menkes/PER/IX/1990

Valerij Shygonskyj, Natalia Shygonska. 2016. Assessment of drinking water quality as a factor affecting human health in Zhytomyr Region. Elsevier. 1-1. 